Scientific journal

PHYSICAL AND MATHEMATICAL EDUCATION

Has been issued since 2013.

Науковий журнал

ФІЗИКО-МАТЕМАТИЧНА ОСВІТА

Видається з 2013.
ISSN 2413-158X (online)
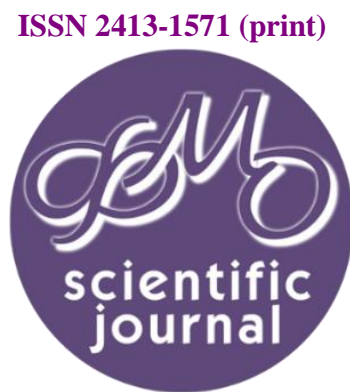

Базурін В.М. Міжпредметні задачі як один із шляхів реалізації практико-орієнтованого підходу у навчанні загальної фізики майбутніх вчителів трудового навчання та технологій. Фізико-математична освіта. 2018. Випуск 1(15). C. $103-107$.

Bazurin V. Interdisciplinary Problems As One Of The Ways Of Implementation Of Practical-Oriented Approach In Teaching Of General Physics Of Future Teachers Of Labor Education And Technologies. Physical and Mathematical Education. 2018. Issue 1(15). P. 103-107.

UDC 378:53

\title{
INTERDISCIPLINARY PROBLEMS AS ONE OF THE WAYS OF IMPLEMENTATION OF PRACTICAL-ORIENTED APPROACH IN TEACHING OF GENERAL PHYSICS OF FUTURE TEACHERS OF LABOR EDUCATION AND TECHNOLOGIES
}

Abstract. General physics is one of the fundamental disciplines studied by future teachers of labor education and technology. An important factor influencing the motivation of students to study general physics is a practice-oriented approach. The main means of learning at the same time are practical-oriented tasks, including tasks of interdisciplinary nature. The article proposes the topics and contents interdisciplinary tasks of general physics for students of the specialty 014.10 "Secondary education. Labor training and technology".

The author proposes a set of tasks on the main topics studied by future technology teachers: kinematics, dynamics, dynamics of solids, dynamics of liquids and gases, conservation laws, thermodynamics, laws of direct and alternating current, optics. The developed tasks belong to the main topics in physics, which are studied by future teachers of labor studies and technologies: kinematics, dynamics, dynamics of solids, dynamics of liquids and gases, conservation laws, the basis of thermodynamics, the laws of constant and alternating current, geometric optics.

The content of the developed tasks is organically linked with the content of such disciplines as resistance of materials, technical mechanics, thermal and hydraulic machines, technological workshops, tractors and cars. The developed interdisciplinary tasks are important for increasing the motivation of students to study general physics, since they ensure compliance with such a didactic principle, as a connection between theory and practice.

The prospect of further research in this direction is to develop a system of practical-oriented tasks in general physics as well as an experimental verification of their impact on the motivation and success of the students.

Key words: general Physics; future teachers; labor training and technology.

Formulation of the problem. Recently, there has been a decline in the level of knowledge and skills of entrants who enter higher education institutions, including pedagogical ones. This is especially evident from the example of students who transfer STIs from physics, but physics is not a discipline for them. These specialties include 014.10 "Secondary education. Labor training and technology». Experience shows that students of these specialties have a low level of motivation to study general physics, moreover, this discipline has undergone significant reductions. This requires students to have a significant amount of independent work, but its effectiveness remains low. The main reasons are low level of motivation and lack of independent work skills.

However, general physics is a fundamental discipline for students of specialties 014.10 "Secondary education. Labor training and technology". Its study is based on such disciplines as theoretical mechanics, resistance of materials, theory of machines and mechanisms, construction mechanics, reinforced concrete structures, hydraulic and thermal machines, etc. Without a thorough knowledge of physics and the ability to make calculations for future technology teachers and faculty of practical training, it will be difficult to master these disciplines - but these disciplines play an important role in shaping their professional competence.

In order for the process of studying general physics to be more effective, it is necessary to increase their level of motivation, and to improve the motivation of students to study general physics, it is expedient to use a practical approach. One of the ways to implement a practical approach to the study of general physics is to use situational tasks. According to the scholars $[6, p .4]$, physical tasks of interdisciplinary nature are capable of linking some abstract nature of physical problems with those professional disciplines, the motivation to study which students have the highest.

Analysis of actual research. A wide range of problems of studying physics of students of higher educational institutions was solved in the studies of B.S. Sus, V.P. Sergiyenko, L.G. Sergiyenko and other scientists. 
Theoretical and methodological principles of teaching the physics of future teachers of non-physical specialties were studied by A.M. Sil"vejstr [6].

In particular, I.T. Bohdanov substantiated the content and methods of teaching general physics of students of nonphysical specialties of higher pedagogical educational institutions [4]. M.I. Shatkovs'ka studied theoretical and methodological principles of integration of knowledge of students in physics and chemistry [7].

Interdisciplinary connections of the discipline "General Physics" are at the center of attention of such scholars as L.Yu. Blahodarenko [3], M.I. Shut [3].

However, the content and subjects of practical-oriented tasks in physics for students of specialties 014.10 "Secondary education remain. Labor training and technology».

The purpose of the article. Taking into account the above-mentioned goal of the article, it is to determine the content of intersubject problems in physics for students of specialties 014.10 "Secondary education. Labor training and technology "related to the disciplines of the cycle of vocational training.

Presenting main material. In the study of general physics students of non-physical specialties have found application elements of different approaches. In our opinion, the most important place belongs to the system approach, because the educational process is considered as an integral system consisting of a number of interrelated components: learning (student activity), teaching (teacher's activity).

Within the framework of a systematic approach to the teaching of general physics of future teachers of labor training and technologies, the following approaches were also reflected: task-oriented, research-oriented, practical-oriented, and others.

As we have already noted, a practical approach is important in teaching physics students of the specialty 014.10 "Secondary education. Labor training and technology". The peculiarities of applying a practical approach to teaching general physics of future teachers of labor education and technology were discussed in [8].

Researchers [5] note that the main means of learning for a practice-oriented approach is a situational task.

Situation problem - this is a task that contains a description of a particular situation, usually problematic [1].

Situation tasks are divided into three groups:

1) interdisciplinary (interdisciplinary) tasks;

2) tasks related to the environment of students;

3) tasks of professional direction [1].

It is expedient to apply the tasks of the first and third groups in higher educational establishments.

Given the topic of research, we are more interested in interdisciplinary tasks. In order to determine the content of interdisciplinary tasks, it is necessary to analyze the curricula of specialties 014.10 "Secondary education. Labor training and technologies".

Students studying in the specialty 014.10 "Secondary education. Labor studies and technologies", study the following disciplines: higher mathematics, engineering graphics (pictorial geometry and drawing), resistance to materials, theory of machines and mechanisms, technical mechanics, technological workshops, and others. Most of these disciplines are professionally-oriented. Moreover, it is important to separate the disciplines for which general physics is the foundation (theory of machines and mechanisms, material resistance, technical mechanics, etc.).

Technological workshop is one of the disciplines of the cycle of professional training. This discipline is taught almost simultaneously with general physics (second semester), therefore interdisciplinary tasks organically combine these disciplines.

If we analyze the training program of the discipline "Technological Workshop", then we can conclude that most of its topics are based on students' knowledge of the physical processes associated with the majority of sections of physics that are studied by students of the specialty. The main types of tasks are shown in Table 1.

Interdisciplinary connections of disciplines "General Physics" and "Technological Practice"

Table 1. (on an example of problems in physics)

\begin{tabular}{|l|l|l|}
\hline General Physics & \multicolumn{1}{|c|}{ Technological Workshop } & \multicolumn{1}{c|}{ Types of tasks } \\
\hline Kinematics & $\begin{array}{l}\text { Continuous movement of manual } \\
\text { and mechanized tools } \\
\text { Rotational motion and mechanized } \\
\text { tools } \\
\text { Continuous motion in the machine } \\
\text { tools } \\
\text { Rotary motion in machine tools }\end{array}$ & $\begin{array}{l}\text { Determination of speed, acceleration of the translational and } \\
\text { rotational motion of manual and mechanized tools } \\
\text { Determination of normal, tangential and angular acceleration } \\
\text { during rotational movement } \\
\text { Determination of linear and angular velocity during rotational } \\
\text { motion }\end{array}$ \\
\hline Dynamics & The forces acting on the cutting tool & Determination of the forces acting on the cutting tool \\
\hline $\begin{array}{l}\text { Solid state } \\
\text { dynamics }\end{array}$ & $\begin{array}{l}\text { Kinetic energy of the rotational } \\
\text { workpiece }\end{array}$ & $\begin{array}{l}\text { Determination of the kinetic energy of the rotational workpiece } \\
\text { movement } \\
\text { Determination of machine power }\end{array}$ \\
\hline $\begin{array}{l}\text { Fundamentals of } \\
\text { thermodynamics }\end{array}$ & $\begin{array}{l}\text { Heating the workpiece and cutting } \\
\text { tool } \\
\text { Aggregate states of matter } \\
\text { Thermal expansion of solids }\end{array}$ & $\begin{array}{l}\text { Determination of the temperature, the heating time of the } \\
\text { workpiece and the cutting tool } \\
\text { Determination of heat consumed by solder melting } \\
\text { Determination of the change in the size of solids due to heating }\end{array}$ \\
\hline $\begin{array}{l}\text { Laws of constant } \\
\text { and alternating } \\
\text { current }\end{array}$ & $\begin{array}{l}\text { Electric circuit parameters } \\
\text { Power of electric tools } \\
\text { Current values of voltage and current }\end{array}$ & $\begin{array}{l}\text { Determination of electric circuit parameters } \\
\text { Determination of power of mechanized tools with electric drive } \\
\text { Determination of AC parameters }\end{array}$ \\
\hline Optics & $\begin{array}{l}\text { Lighting of the workplace } \\
\text { Determining the lighting conditions of the workplaces }\end{array}$ \\
\hline
\end{tabular}


Consider examples of interdisciplinary tasks from different sections of general physics related to the content of the discipline "Technological Practice".

Kinematics.

1. Determine the speed of the incisor relative to the surface of the workpiece, rotating in the lathe cartridge, if the rotational speed is $120 \mathrm{rpm}$, the diameter of the workpiece is $110 \mathrm{~mm}$.

2. A $12 \mathrm{~mm}$ diameter drill rotates with a frequency of $120 \mathrm{rpm}$. The drill feed is $0.1 \mathrm{~mm} / \mathrm{rev}$. Determine the absolute speed of the point that lies on the outer surface of the drill.

3. In the cartridge of the lathe, a cylindrical billet with a diameter of $110 \mathrm{~mm}$ is rotated. Determine the normal acceleration and linear velocity of the point, which is on the outer surface of the workpiece, if the spindle speed is: 1) $120 \mathrm{rpm}$; 2) $650 \mathrm{rpm}$; 3) $720 \mathrm{rpm}$; 4) $1040 \mathrm{rpm}$

4. In the cartridge of the lathe, a cylindrical billet with a diameter of $105 \mathrm{~mm}$ and a length of $180 \mathrm{~mm}$ is rotated. Determine the angular velocity and normal acceleration of the point that lies on the generating cylinder, if the spindle speed is $650 \mathrm{rpm}$.

5. In the cartridge of the lathe TG-6 rotates a cylindrical billet with a diameter of $180 \mathrm{~mm}$. Determine the normal acceleration and the linear velocity of the point lying on the outer surface of the workpiece for the rotational speeds of 385,510 , $700 \mathrm{rpm}$.

6. The turning speed of the spindle of the lathe is $16 \mathrm{~K} 20$ equal to $2000 \mathrm{rpm}$, feed $-2.8 \mathrm{~mm} / \mathrm{rev}$. Determine the speed of the cutter in the horizontal direction.

7. The turning speed of the spindle of the lathe is $16 \mathrm{~K} 20$ equal to $500 \mathrm{rpm}$, the feed is $0.6 \mathrm{~mm} / \mathrm{rev}$. The cartridge is secured with a cylindrical billet with a diameter of $180 \mathrm{~mm}$. Determine the speed of the cutter in the horizontal direction, as well as the speed of the cutter relative to the surface of the workpiece.

Dynamics.

1. The locksmith acts on a file with a force of $40 \mathrm{~N}$, directed at an angle of $30^{\circ}$ to the surface of the file. Determine the vertical and horizontal components of force.

2. During the drilling of the hole in the workpiece, the worker presses the knob of the machine $2 \mathrm{H} 118$ with an effort of $60 \mathrm{~N}$. Determine the force with which the drill acts on the workpiece, if the handle length is $40 \mathrm{~cm}$, and the shoulder of the lever acting on the spindle is $5 \mathrm{~cm}$.

Solid state dynamics.

1. In the cartridge of the lathe, an aluminum billet with a diameter of $120 \mathrm{~mm}$ and a length of $100 \mathrm{~mm}$ is secured. The workpiece rotates at a frequency of $650 \mathrm{rpm}$. Determine the kinetic energy of the rotational motion.

2. In the cartridge of the lathe, a cylindrical billet with a diameter of $120 \mathrm{~mm}$ and a length of $300 \mathrm{~mm}$, made of copper, is fixed. Determine the energy of the rotary motion of the workpiece at a rotational speed of $800 \mathrm{rev} / \mathrm{in} . .1,000 \mathrm{rev} / \mathrm{in} . .2000 \mathrm{rev}$ / in ..

3. The engine power of the lathe $16 \mathrm{~K} 20$ is $10 \mathrm{~kW}$, and the efficiency is 0.75 . In the cartridge the machine is fixed a steel workpiece of the type "stepped shaft", which consists of 3 stages with diameters, respectively, $100 \mathrm{~mm}, 60 \mathrm{~mm}, 40 \mathrm{~mm}$. The lengths of the steps are respectively $80 \mathrm{~mm}, 120 \mathrm{~mm}$ and $200 \mathrm{~mm}$. Determine the time required to unpack the workpiece to a rotational speed of $2000 \mathrm{rpm}$.

Fundamentals of thermodynamics.

1. Determine the efficiency of the solder with a rated power of $50 \mathrm{~W}$, if for melting a drop of 2 grams of tin dropped at room temperature, it takes 20 seconds.

2. During the processing of aluminum workpiece on a lathe, it was heated to $70^{\circ} \mathrm{C}$. Determine the diameter to which the workpiece must be sharpened if its diameter after cooling to room temperature should be $104 \mathrm{~mm}$.

Laws of constant and alternating current.

1. The electric heating device has an efficiency of $40 \%$ and is designed for voltage of $220 \mathrm{~V}$ (active value). Determine the strength of current consumed by this device, if to bring to a boil 1.5 liters of water is 10 minutes. The initial water temperature is $20^{\circ} \mathrm{C}$.

2. The power of the electric motor of the lathe $16 \mathrm{~K} 20$ is $10 \mathrm{~kW}$, and the efficiency coefficient is $75 \%$. The steel billet with a diameter of $20 \mathrm{~cm}$ and a length of $30 \mathrm{~cm}$ is rolled up to a rotational speed of $2000 \mathrm{rpm}$. for $30 \mathrm{~s}$. Determine the efficiency of the machine.

Another important discipline is the cycle of training - "Tractors and cars". This discipline involves studying the following main topics: engine power system; crank mechanism; engine cooling system; engine lubrication system; brake system of the car; electrical equipment of the car; car chassis. After analyzing the curriculum in this discipline, we found that most topics are organically linked to the physical phenomena on which the principle of the operation of a car device is based.

The main types of tasks are shown in Table 2.

Here are examples of interdisciplinary tasks in accordance with the sections of physics.

Kinematics.

1. Determine the centripetal acceleration of the $\mathrm{KrAZ}$ vehicle, which moves at a speed of $60 \mathrm{~km} / \mathrm{h}$ in the rounding of the path with a radius of $40 \mathrm{~m}$.

2. The length of the braking distance of the car is $4 \mathrm{~m}$. Determine the acceleration experienced by the vehicle if its initial speed is $60 \mathrm{~km} / \mathrm{h}$.

Dynamics.

1. The tractor KhTZ-17221 develops power $175 \mathrm{hp}$ and drives a 7-hole plow at a speed of $8 \mathrm{~km} / \mathrm{h}$. Determine the strength of soil resistance.

2. The KrAZ-256B car at a full weight of $23.5 \mathrm{t}$ develops a speed of $68 \mathrm{~km} / \mathrm{h}$. The power of the YMZ-238 engine installed on the car is $240 \mathrm{hp}$ Determine the efficiency of the engine. 
Table 2.

Interdisciplinary connections of disciplines "General physics" and "Tractors and cars" (on an example of problems in physics)

\begin{tabular}{|c|c|c|}
\hline General Physics & Tractors and cars & Types of tasks \\
\hline Kinematics & $\begin{array}{l}\text { Progressive and rotational } \\
\text { motion of cars } \\
\text { Progressive movement of } \\
\text { the piston, pusher } \\
\text { Rotary shaft movement, } \\
\text { flywheel }\end{array}$ & $\begin{array}{l}\text { Determination of speed and acceleration of cars with translational } \\
\text { and rotational motion } \\
\text { Determination of linear speed and linear acceleration of a piston } \\
\text { or pusher } \\
\text { Determination of the linear and angular velocity of the rotational } \\
\text { motion of the flywheel, shaft } \\
\text { Determination of normal, tangential and angular acceleration of } \\
\text { the rotational motion of the flywheel, shaft }\end{array}$ \\
\hline Dynamics & $\begin{array}{l}\text { Continuous motion of cars } \\
\text { Progressive movement of } \\
\text { the piston, pusher }\end{array}$ & Determination of the braking distance of the car \\
\hline Solid state dynamics & $\begin{array}{l}\text { Rotary shaft movement, } \\
\text { flywheel } \\
\text { Flexible push pusher } \\
\text { movement }\end{array}$ & $\begin{array}{l}\text { Determination of the time of rotation of the flywheel } \\
\text { Determination of the energy of the rotational motion of the } \\
\text { flywheel, shaft } \\
\text { Determination of forces acting on the flywheel during rotational } \\
\text { movement }\end{array}$ \\
\hline $\begin{array}{l}\text { Dynamics of liquids } \\
\text { and gases }\end{array}$ & Brake system of the car & Determination of the force of pressure on the brake pads \\
\hline $\begin{array}{ll}\text { Fundamentals of } \\
\text { thermodynamics }\end{array}$ & $\begin{array}{l}\text { Power of the internal } \\
\text { combustion engine } \\
\text { Heating of solids and liquids } \\
\text { Aggregate states of matter } \\
\text { Thermal expansion of solids } \\
\text { and liquids }\end{array}$ & $\begin{array}{l}\text { Determination of power, efficiency of internal combustion engine } \\
\text { Determination of gas pressure on the piston } \\
\text { Determination of the heat expended on the transformation of a } \\
\text { substance from one aggregate state to another } \\
\text { Determination of fluid volume due to heating } \\
\text { Determination of body size due to heating }\end{array}$ \\
\hline $\begin{array}{l}\text { Laws of constant and } \\
\text { alternating current }\end{array}$ & $\begin{array}{l}\text { Electric circuit parameters } \\
\text { Work and power of electric } \\
\text { current } \\
\text { Battery charge and discharge }\end{array}$ & $\begin{array}{l}\text { Determination of the current and voltage in the electric circuit and } \\
\text { in the electric circuit } \\
\text { Determination of the electric current in the heating elements } \\
\text { Determine the capacity and battery charging time }\end{array}$ \\
\hline Optics & $\begin{array}{l}\text { Light } \\
\text { Geometric optics }\end{array}$ & $\begin{array}{l}\text { Determination of illumination from a light source } \\
\text { Construction of images in spherical mirrors }\end{array}$ \\
\hline
\end{tabular}

Solid state dynamics

1. The flywheel of the engine weighing $60 \mathrm{~kg}$ and $60 \mathrm{~cm}$ in diameter is uncoupled to a rotational speed of $2400 \mathrm{rpm}$. in 1 min Determine engine power if its efficiency is 0.33 .

2. Determine the moment of inertia of the wheel of the car, which has a mass of $40 \mathrm{~kg}$. Consider the wheel with a disk with a cavity inside, the outer diameter of which is $80 \mathrm{~cm}$, and the inner diameter is $30 \mathrm{~cm}$.

Dynamics of liquids and gases

1. A person presses a brake with an effort of $100 \mathrm{~N}$. The diameter of the piston associated with the brake pedal is $2 \mathrm{~cm} 2$. The diameter of the piston that drives the brake pads is $6 \mathrm{~cm}$. Determine the force with which the brake pad acts on the wheel.

2. In each of the four chambers of the car, a pressure of $2.2 \mathrm{~atm}$ was established. The weight of the car equals 1.6 tons. Determine the area of the support of the tire on the surface of the road.

Thermodynamics

1. The tractor KhTZ-17221 develops power $175 \mathrm{hp}$ and spends diesel fuel $251 \mathrm{~g} / \mathrm{kWh}$. Determine the efficiency of the engine.

2. The engine of the car has a power of $100 \mathrm{hp}$ and heats up to the operating temperature $\left(90^{\circ} \mathrm{C}\right)$ for 10 minutes. Initial engine temperature is $-10^{\circ} \mathrm{C}$. The volume of the cooling fluid is 7 liters, and its heat capacity is $4200 \mathrm{~J} / \mathrm{kg} \bullet \mathrm{K}$. Determine which part of the engine power is consumed to heat the engine.

The laws of constant and alternating current

1. There are two identical light bulbs in power supply of $10 \mathrm{~W}$ in parallel to the power supply of the car with $12 \mathrm{~V}$ voltage. Determine how many times the power consumed by these bulbs changes if you turn them on sequentially.

2. The car battery has a capacity of $600 \mathrm{~A}-\mathrm{h}$ and is charged with a current of $10 \mathrm{~A}$. Determine the time of charging the battery.

Conclusions. Practical-orientated approach in teaching physics of students of the specialty 014.10 «Secondary education. Labor training and technology "plays an important role in motivating students. The main means of teaching is a practical-oriented task. In the practice of teaching physics in higher educational institutions, it is advisable to apply practical-oriented tasks of two types: interdisciplinary and professional-purpose tasks.

Disciplines "Technological Practicum" and "Tractors and cars" have themes, in the study of which it is advisable to rely on the knowledge of students in physics. There is a wide range of physical tasks, the content of which is related to the content of disciplines "Technological Practice" and "Tractors and cars". It is expedient to elaborate the tasks of the problem, as well as develop a system of problems of professionally oriented content.

Prospects for further research are the development of a system of interdisciplinary tasks and the study of their impact on the level of student motivation and their success. 


\section{References}

1. Alfereva M.K. Blog of the teacher of computer science and mathematics Practical-oriented approach in teaching computer science. URL: http://amk64.blogspot.com/2013/10/blog-post_26.html. (accessed by 05.08.2017).

2. Atamanchuk P.S., Semernya O.M. Peculiarities of the formation of the educational environment in physics in the conditions of the implementation of interdisciplinary connections. Pedagogical sciences: zb.nauk.prats. Kherson, 2008. №50-2. P.11-15.

3. Blahodarenko L.Yu., Shut M.I. The new educational program for physics for students of the direction of training "Physics" of pedagogical universities. Scientific journal of the National Pedagogical University named after M.P. Dragomanov. Series 3: Physics and Mathematics at Higher and Secondary School. 2013. Vyp. 11. P. 14-18. URL: http://enpuir.npu.edu.ua/bitstream/123456789/15479/1/Blagodarenko_Shut.pdf (accessed by: 21.01.2018).

4. Bohdanov I.T. Methodology of teaching general physics at faculties of non-physical specialties in higher educational pedagogical institutions: Autoref.dis ... .Kand.Ped.Nauk: 13.00.02 - Theory and methods of teaching (physics). K., 2003. 21 p.

5. Nykolaeva M.A., Kalachev S.L., Kartashova L.V. Methodology of development and application of situational tasks intended for formation of professional competences. Word to teacher. URL: http://slovo.mosmetod.ru/avtorskie-materialy/item/912nikolaeva-m-a-kalachjov-s-I-kartashova-I-v-metodika-razrabotki-i-primeneniya-situatsionnykh-zadach-prednaznachennykhdlya-formirovaniya-professionalnykh-kompetentsij/912-nikolaeva-m-a-kalachjov-s-I-kartashova-l-v-metodika-razrabotki-iprimeneniya-situatsionnykh-zadach-prednaznachennykh-dlya-formirovaniya-professionalnykh-kompetentsij . (accessed by: 05.08.2017).

6. Sil"vejstr A.M. Theoretical and methodical principles of teaching the physics of future teachers of chemistry and biology: dis .... .dr.pd. Science: 13.00.02 - Theory and methods of teaching (physics). Kropyvnyc"kyj, 2017. 512 p.

7. Shatkovs"ka H.I. Scientific and methodical principles of integration of knowledge of physics and chemistry of students of higher educational institutions of the I-II levels of accreditation of the technical and technological profile: author's dissertation ... candidate of science. 13.00.02 - theory and methods of teaching (physics). K., 2007. 26 p.

8. Bazurin V.M. Practical-oriented approach in field of physics of future teachers of professional education and teachers of technologies. Physical and Mathematical Education : scientific journal. 2017. Issue 3(13). P. 20-25. URL: http://fmojournal.fizmatsspu.sumy.ua/publ/2-1-0-199. (accessed by: 15.02.2018).

\section{МІЖПРЕДМЕТНІ ЗАДАЧІ ЯК ОДИН ІЗ ШЛЯХІВ РЕАЛІЗАЦІЇ ПРАКТИКО-ОРІЄНТОВАНОГО ПІДХОДУ У НАВЧАННІ ЗАГАЛЬНОЇ ФІЗИКИ МАЙБУТНІХ ВЧИТЕЛІВ ТРУДОВОГО НАВЧАННЯ ТА ТЕХНОЛОГІЙ В.М. Базурін}

Глухівський національний педагогічний університет імені Олександра Довженка, Україна

Анотація. Загальна фізика є однією з фундаментальних дисциплін, які вивчають майбутні вчителі трудового навчання та технологій. Важливим чинником, що впливає на мотивацію студентів до вивчення загальної фізики, $\epsilon$ практико-орієнтовний підхід. Основними засобами навчання при цьому є практико-орієнтовані задачі, у тому числі задачі міжпредметного характеру. У статті запропонована тематика і зміст міжпредметних задач з загальної фізики для студентів спеціальності 014.10 «Середня освіта. Трудове навчання та технології».

Автор визначає міжпредметні зв'язки курсу загальної фізики з дисциплінами фахової спрямованості, такими як "Технологічний практикум» $i$ «Трактори і автомобілі».

Автор пропонує набір задач за основними темами, що вивчаються майбутніми учителями технологій: кінематика, динаміка, динаміка твердого тіла, динаміка рідин і газів, закони збереження, термодинаміка, закони постійного і змінного струму, оптика. Розроблені задачі належать до основних тем з фізики, які вивчаються майбутніми вчителями трудового навчання та технологій: кінематика, динаміка, динаміка твердого тіла, динаміка рідин і газів, закони збереження, основи термодинаміки, закони постійного та змінного електричного струму, геометрична оптика.

Зміст розроблених задач органічно пов'язаний зі змістом таких дисциплін, як опір матеріалів, технічна механіка, теплові та гідравлічні машини, технологічний практикум, трактори та автомобілі.

Розроблені міжпредметні задачі мають важливе значення для підвищення мотивації студентів до вивчення загальної фізики, оскільки забезпечують дотримання такого дидактичного принципу, як зв'язок теорії з практикою.

Перспектива подальших досліджень у даному напрямі полягає у розробці системи практико-орієнтованих задач з загальної фізики а також експериментальна перевірка їх впливу на мотивацію та успішність студентів.

Ключові слова: загальна фізика; майбутні вчителі; трудове навчання та технології. 